\title{
NATURAL INFECTIONS OF BLACKFLIES WITH LARVAE OF ZOONOTIC ONCHOCERCA SPP. IN NORTHEAST JAPAN
}

\author{
Hiroyuki TAKaOKA ${ }^{1}$, Chiharu AOKI ${ }^{1}$ AND Hirofumi Hayakawa ${ }^{2}$ \\ Received November 29 1991/Accepted January 161992
}

\begin{abstract}
Dissections of female blackflies collected while attacking a cow at the Omyojin Farm, Iwate, northern Japan showed that 4.4\% of 1,104 Simulium daisense, 0.8\% of 913 S. aokii, $0.5 \%$ of 741 S. iwatense and $0.9 \%$ of 340 S. nikkoense examined were naturally infected with filarial larvae. There were at least two types of third-stage larvae assignable to Onchocerca, of which type A found in S. daisense and S. aokii measured 914$1,212 \mu \mathrm{m}$ long by $26-29 \mu \mathrm{m}$ wide while type B found in $S$. daisense had its body size of $369-$ $477 \mu \mathrm{m}$ long by $14.9-17.9 \mu \mathrm{m}$ wide. Morphometric observations suggest that types $\mathrm{A}$ and $\mathrm{B}$ each correspond to types I and III previously recorded in Kyushu, southwest Japan as the third-stage larvae of bovine Onchocerca (i.e., $O$. sp. and O. lienalis). This is the first record for natural infection of blackflies in Honshu (main island of Japan) with zoonotic Onchocerca larvae.
\end{abstract}

\section{INTRODUCTION}

In relation to the transmission of bovine and equine onchocerciasis in Japan, Hosoya et al. (1956) dissected several species of Simulium and Culicoides collected in the endemic areas, such as Tottori in western Honshu, Fukushima and Aomori in northern Honshu, but failed to detect any larvae of Onchocerca, though they found some flies infected with larvae of nonfilarial nematodes bearing a sharply pointed tail. Ueno et al. (1956) also examined about 16,000 females of four Culicoides species caught by light traps in Tokyo and found no Onchocerca larvae. There was since then no investigation on the vectors of these zoonotic onchocerciasis in Japan. Recently, we found that several blackfly species collected at cattle sheds in Kyushu, southwest Japan were naturally infected with three types of Onchocerca larvae, of which two (types II and III) were each suspected as $O$. gutturosa Neumann and $O$. lienalis Stiles parasitizing cattle while the last (type I) remained unidentified (Takaoka and Bain, 1990). Subsequent infection experiments showed that microfilariae from the skins of slaughtered cattle or from the midgut of freshly blood fed blackflies successfully developed in blackflies to the third-stage larvae $\left(\mathrm{L}_{3}\right)$ almost identical to those of types I and III, (Takaoka, 1990). From the results of these and other works, it is now clarified that $S$. bidentatum (Shiraki) and $S$. arakawae Matsumura are the natural vectors of type I $(O . \mathrm{sp}$.$) ,$

1 Division of Medical Zoology, Oita Medical University, Hasama, Oita 879-55, Japan

2 Department of Animal Production, Tohoku National Agricultural Experimental Station, Morioka 020-01, Japan 
the former also serves as a vector of type II (probably O. gutturosa) and the latter as well as S. kyushuense Takaoka is also a natural vector of type III (=O. lienalis) in Kyushu (Takaoka, in preparation).

The present work was done in Iwate, northeast Japan to determine whether some other blackfly species are also involved in the transmission of zoonotic onchocerciasis. In this paper, two more blackfly species are added as a natural vector of zoonotic Onchocerca spp. (probably $O$. sp. and $O$. lienalis) .

\section{MATERIAL AND METHODS}

Collections of adult blackflies were carried out at the Omyojin Farm (at about $40^{\circ} \mathrm{N}$ lat. and $141^{\circ}$ E long.; $230-270 \mathrm{~m}$ in altitude), Faculty of Agriculture, Iwate University, at Shizukuishi-machi, Iwate Prefecture, in northeast Japan, from April to November in 1989. About 80 cattle were bred in the pasture (ca. $45 \mathrm{ha}$ ) of this farm. An hourly 10-minute collection of flies attacking a cow tethered to the wooden fence was made once a month using an insect net by one man, for $24 \mathrm{hrs}$ starting from 11:00 hr. Air temperatures were hourly measured at the end of each collection. This regular collection was attempted to determine the seasonal pattern in biting activity of blackflies. Females captured were preserved in small vials with $80 \%$ ethanol solution, and sent to the laboratory in Oita. After being identified to species, these specimens were dissected in $5 \%$ Giemsa solution on glass slide under dissecting microscope and examined for filarial larvae. In addition to samples from regular collections, portions of female blackflies captured by a cow-baited trap and/or a $\mathrm{CO}_{2}$ trap which were set at the same place and time were, if necessary, also dissected in the similar manner. Morphometric observations were microscopically made for all filarial larvae detected. Generic diagnosis of $\mathrm{L}_{3}$ larvae followed that of Bain and Chabaud (1986).

\section{RESULTS}

Table 1 shows the results of regular collections. At least 12 blackfly species belonging to Prosimulium, Cnephia and Simulium were collected. The biting activity of Pro. yezoense Shiraki was high in May but very low or nil in the following months. On the other hand, biting activity of most Simulium species became marked after May, continued to be relatively high until August with their peak in June or July and decreased in September. Thereafter, biting activity was still observed in several species but in small numbers except S. aokii (Takahasi). Among Simulium species, the most abundant were S. aokii and S. daisense (Takahasi), followed by $S$. iwatense (Shiraki) during the summer months from June to August.

In view of the critical air temperature of ca. $17^{\circ} \mathrm{C}$ below which larval development of $O$. volvulus (Leuckart) in the intermediate blackflies would cease (Takaoka et al., 1982), dissections for natural infections with any filarial larvae were made only for samples of four Simulium species which were relatively abundant during a period from June to September when air temperatures were for the most part beyond $17^{\circ} \mathrm{C}$ (Fig. 1). The results of dissections are presented in Table 2 .

All the four species dissected harboured filarial larvae in their thoracic and/or cephalic regions. The overall infection rates varied from $0.5 \%$ to $4.4 \%$ depending on the species. 
Table 1 Number of female blackflies captured by a sweeping net on cattle at the Omyojin Farm, Iwate, northeast Japan, in 1989*

\begin{tabular}{lrrrrrrrr}
\hline \multirow{2}{*}{ Blackfly species } & \multicolumn{7}{c}{ Months of collection } \\
\cline { 2 - 9 } & Apr. & May & Jun. & Jul. & Aug. & Sep. & Oct. & Nov. \\
\hline Prosimulium yezoense & 0 & 398 & 9 & 1 & 0 & 0 & 0 & 0 \\
Other Prosimulim spp. & 26 & 49 & 0 & 0 & 0 & 0 & 0 & 0 \\
Cnephia sp. & 2 & 19 & 0 & 0 & 0 & 0 & 0 & 0 \\
Simulium uchidai & 0 & 0 & 4 & 1 & 0 & 0 & 0 & 0 \\
S. aokii & 9 & 10 & 146 & 281 & 207 & 12 & 55 & 189 \\
S. arakawae & 0 & 3 & 0 & 11 & 16 & 0 & 2 & 1 \\
S. daisense & 0 & 0 & 722 & 201 & 108 & 9 & 5 & 0 \\
S. iwatense & 43 & 2 & 132 & 91 & 28 & 0 & 6 & 2 \\
S. japonicum/kawamurae & 4 & 50 & 2 & 8 & 0 & 2 & 34 & 0 \\
S. nacojapi & 0 & 0 & 0 & 1 & 0 & 0 & 0 & 0 \\
S. nikkoense & 0 & 1 & 16 & 71 & 15 & 0 & 0 & 1 \\
S. rufibasis & 0 & 0 & 3 & 3 & 1 & 0 & 0 & 0 \\
\hline Total & 84 & 532 & 1,034 & 669 & 375 & 23 & 102 & 193 \\
\hline
\end{tabular}

*: An hourly 10-minute collection was made for consecutive $24 \mathrm{hrs}$ by one man, once a month.

Table 2 Natural filarial infections of blackfies collected on cattle at the Omyojin Farm, Iwate, northeast Japan

\begin{tabular}{|c|c|c|c|c|c|}
\hline \multirow{2}{*}{ Blackfly species } & \multicolumn{4}{|c|}{ Months of collection } & \multirow{2}{*}{ Total } \\
\hline & Jun. & Jul. & Aug. & Sep. & \\
\hline \multicolumn{6}{|l|}{ S. aokii } \\
\hline No. infected/no. dissected & $3 / 210$ & $1 / 247$ & $2 / 310$ & $1 / 146$ & \multirow[t]{4}{*}{$7 / 913(0.8 \%)$} \\
\hline No. and stage ${ }^{a}$ of larvae & $4 \mathrm{~L}_{1}$ & $1 \mathrm{~L}_{3}$ & $2 \mathrm{~L}_{1}$ & $4 \mathrm{~L}_{2}$ & \\
\hline No. larvae/infected fly & & & & & \\
\hline Median (Range) & $1(1-2)$ & $1(1)$ & $1(1)$ & $4(4)$ & \\
\hline \multicolumn{6}{|l|}{ S. daisense } \\
\hline No. infected/no. dissected & $17 / 569^{\mathrm{b}}$ & $29 / 202$ & $1 / 281$ & $1 / 52$ & \multirow[t]{4}{*}{$48 / 1,104(4.4 \%)$} \\
\hline No. and stage of larvae & $54 \mathrm{~L}_{1}+1 \mathrm{~L}_{2}$ & $6 \mathrm{Mf}+56 \mathrm{~L}_{1}+29 \mathrm{~L}_{2}+39 \mathrm{~L}_{3}$ & $2 \mathrm{~L}_{1}$ & $3 \mathrm{~L}_{2}$ & \\
\hline No. larvae/infected fly & & & & & \\
\hline Median (Range) & $2(1-13)$ & $4(1-27)$ & $2(2)$ & $3(3)$ & \\
\hline \multicolumn{6}{|l|}{ S. iwatense } \\
\hline No. infected/no. dissected & $0 / 176$ & $3 / 499^{b}$ & $1 / 66$ & $-1-$ & \multirow[t]{4}{*}{$4 / 741(0.5 \%)$} \\
\hline No. and stage of larvae & - & $2 \mathrm{Mf}+2 \mathrm{~L}_{1}+2 \mathrm{~L}_{2}$ & $2 \mathrm{~L}_{1}$ & & \\
\hline No. larvae/infected fly & & & & & \\
\hline Median (Range) & & $2(1-3)$ & $2(2)$ & & \\
\hline \multicolumn{6}{|l|}{ S. nikkoense } \\
\hline No. infected/no. dissected & $-1-$ & $2 / 312$ & $1 / 28$ & $-1-$ & \multirow[t]{4}{*}{$3 / 340(0.9 \%)$} \\
\hline No. and stage of larvae & & $8 \mathrm{~L}_{1}+2 \mathrm{~L}_{2}$ & $23 \mathrm{~L}_{1}$ & & \\
\hline No. larvae/infected fly & & & & & \\
\hline Median (Range) & & $4(1-9)$ & $23(23)$ & & \\
\hline
\end{tabular}

a. Mf, microfilaria; $\mathrm{L}_{1}, \mathrm{~L}_{2}$ and $\mathrm{L}_{3}$ represent first-, second- and third-stage larvae, respectively

b. A larva of non-filaria nematode was found in the thorax of one $S$. daisense and one $S$. iwatense 
Table 3 Measurements of third-stage larvae $\left(\mathrm{L}_{3}\right)$ of Onchocerca spp. found in Simulium aokii and $S$. daisense collected at the Omyojin Farm, Iwate, northeast Japan

\begin{tabular}{|c|c|c|c|c|c|c|c|c|}
\hline \multirow{3}{*}{$\begin{array}{c}\mathrm{L}_{3} \\
\text { no. } \\
1\end{array}$} & \multirow{3}{*}{$\begin{array}{l}\text { Type } \\
\text { of } \mathrm{L}_{3} \\
\mathrm{~A}\end{array}$} & \multirow{2}{*}{\multicolumn{2}{|c|}{$\begin{array}{c}\text { Host Simulium } \\
\text { spp. and body parts }\end{array}$}} & \multicolumn{5}{|c|}{ Landmarks* } \\
\hline & & & & \multirow{2}{*}{$\frac{\mathrm{BL}}{1,212.7}$} & \multirow{2}{*}{$\begin{array}{l}\text { BW } \\
26.6\end{array}$} & \multirow{2}{*}{$\frac{\mathrm{OL} / \mathrm{BL}}{0.49}$} & \multirow{2}{*}{$\frac{\mathrm{TL}}{40.0}$} & \multirow{2}{*}{$\begin{array}{c}\mathrm{TL} / \mathrm{TW} \\
1.79\end{array}$} \\
\hline & & S. aokii & thorax & & & & & \\
\hline 2 & A & S. daisense & thorax & 914.2 & 28.0 & - & - & - \\
\hline 3 & A & 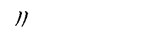 & " & 947.8 & 29.1 & 0.46 & 33.5 & 1.29 \\
\hline 4 & A & " & 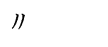 & $1,059.7$ & 26.9 & 0.49 & 43.7 & 1.83 \\
\hline 5 & A & $川$ & $\eta$ & $1,179.1$ & 26.1 & 0.43 & - & - \\
\hline 6 & $\mathrm{~B}$ & " & head & 369.4 & 14.9 & 0.66 & - & - \\
\hline 7 & B & " & $\mu$ & 373.1 & 17.9 & 0.67 & - & - \\
\hline 8 & B & $n$ & $\eta$ & 403.0 & 16.8 & 0.62 & 33.5 & 2.25 \\
\hline 9 & $\mathrm{~B}$ & $\prime \prime$ & $\eta$ & 410.5 & 16.8 & 0.61 & - & - \\
\hline 10 & B & $\prime \prime$ & $\prime \prime$ & 440.3 & 16.8 & - & 33.5 & 2.01 \\
\hline 11 & B & 11 & 11 & 447.8 & 17.9 & 0.62 & - & - \\
\hline 12 & B & "1 & 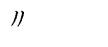 & 447.8 & 16.8 & 0.65 & 29.1 & 2.05 \\
\hline 13 & $\mathrm{~B}$ & $" 1$ & 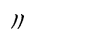 & 447.8 & 15.7 & 0.58 & - & - \\
\hline 14 & B & $m$ & $川$ & 451.5 & 15.7 & 0.69 & 29.8 & 1.95 \\
\hline 15 & B & $m$ & 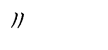 & 462.7 & 16.8 & 0.66 & - & - \\
\hline 16 & B & $m$ & "I & 462.7 & - & 0.68 & - & - \\
\hline 17 & B & 11 & $\prime \prime$ & 466.4 & 16.4 & 0.68 & - & - \\
\hline 18 & $\mathrm{~B}$ & 11 & 11 & 477.6 & 16.4 & 0.63 & 33.5 & 2.25 \\
\hline
\end{tabular}

Filarial larvae found were at various developmental stages (Fig. $2 \mathrm{a}-\mathrm{h}$ ), of which $\mathrm{L}_{3}$ larvae were found only in 1 or $0.4 \%$ of 247 S. aokii and 7 or $3.5 \%$ of 202 S. daisense examined in July.

There are apparently two types of $\mathrm{L}_{3}$ larvae judging from the body size and relative length of oesophagus to whole body, as shown in Table 3. The longer type (designated as type A; Fig. 2h) was found in both of $S$. aokii and S. daisense whereas the shorter one (type B; Fig. 2f) was detected only from the latter blackfly species. Of the seven $S$. daisense infected with $\mathrm{L}_{3}$ larvae, three had type $\mathrm{A}$, while the others harboured type $\mathrm{B}$. One of the four females with $\mathrm{L}_{3}$ of type $\mathrm{B}$ was also infected with two preinfective larvae assignable to type A (Fig. $2 \mathrm{~g}$ ) due to long body size $(630.6 \mu \mathrm{m}$ and $570.9 \mu \mathrm{m})$ and short oesophagus $(0.36 \times$ and $0.34 \times$ body length).

The $\mathrm{L}_{3}$ larvae of type $\mathrm{A}$ were all found in the thorax and their number per infected fly was one or two, whereas those of type B were mostly recovered from the cephalic region and their number varied from 1 to 27 . In one female infected with $27 \mathrm{~L}_{3}$ larvae, all but one were found in the head, in particular, clustering within labrum of the mouthpart (Fig. 3).

Several large second-stage larvae $\left(L_{2}\right)$ (e.g. Fig. $2 g$ ) measuring ca. $400-780 \mu \mathrm{m}$ in body length (i.e., advanced $\mathrm{L}_{2}$ or preinfective) found in $S$. daisense were evidently the same species as the $\mathrm{L}_{3}$ designated type A. However, classification was impossible for most of other smaller $\mathrm{L}_{2}$ (body length ca. 200-290 $\mu \mathrm{m}$ and oesophagus about $1 / 2 \times$ the body length) including four $\mathrm{L}_{2}$ larvae found in $S$. iwatense and S. nikkoense Shiraki (Figs. $2 \mathrm{~d}$ and $2 \mathrm{e}$ ) as well as first-stage 
larvae $\left(\mathrm{L}_{1}\right)$ (ca. 90-170 $\mu \mathrm{m}$ long) (Figs. $2 \mathrm{~b}$ and $2 \mathrm{c}$ ).

Microfilariae (Fig. 2a) were found in the thorax of one S. iwatense and three S. daisense. In the latter three females, $L_{1}$ and/or $L_{2}$ larvae were also found. All these microfilariae were similar in size (i.e., $186.6-223.9 \mu \mathrm{m}$ long by $5.0-5.9 \mu \mathrm{m}$ wide), were unsheathed and had a slender pointed tail.

Two larvae of non-filarial nematode were each found in the thorax of S. iwatense and $S$. daisense. Both of these larvae had a sharply pointed tail (Fig. 2i) and measured $492.5 \mu \mathrm{m}$ long by $14.9 \mu \mathrm{m}$ wide and $856.0 \mu \mathrm{m}$ long by $31.3 \mu \mathrm{m}$ wide, respectively.

\section{Discussion}

The present work shows that four blackfly species attacking cattle in northeast Japan were naturally infected with at least two types of filarial larvae developing in the fly's thorax, which are probably assignable to the genus Onchocerca by the very small, caudal lappets of $\mathrm{L}_{3}$ larva.

Out of two types, type A found in $S$. daisense and $S$. aokii is characterized by the very long body (average $1,062.7 \mu \mathrm{m}$ ) and the short oesophagus $\{(0.43-0.49) \times$ the body length $\}$. With these characters type A does not fit with any known Onchocerca species (Bain and Chabaud, 1986), and reminds us of type $\mathrm{I}_{1} \mathrm{~L}_{3}$ of Onchocerca sp. (body length, 1,075-1,380 $\mu \mathrm{m}$; ratio of oesophagus/body length, $0.45-0.50$ ) which was reported from wild caught $S$.

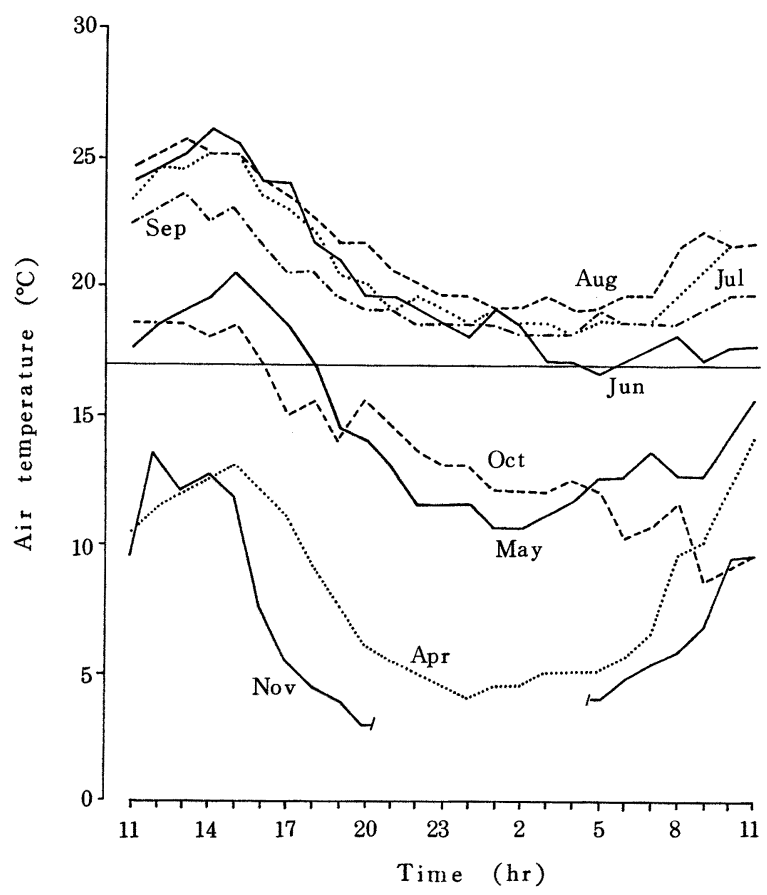

Figure 1 Daily fluctuation of air temperatures by months at the Omyojin Farm, Iwate, northeast Japan. Horizontal line shows a critical air temperature of ca. $17^{\circ} \mathrm{C}$ for development of Onchocerca volvulus larvae in the vector blackfly. Data on air temperatures from 21:00 to $04: 00 \mathrm{hr}$ in November were not available due to the cessation of the collection during the night. 

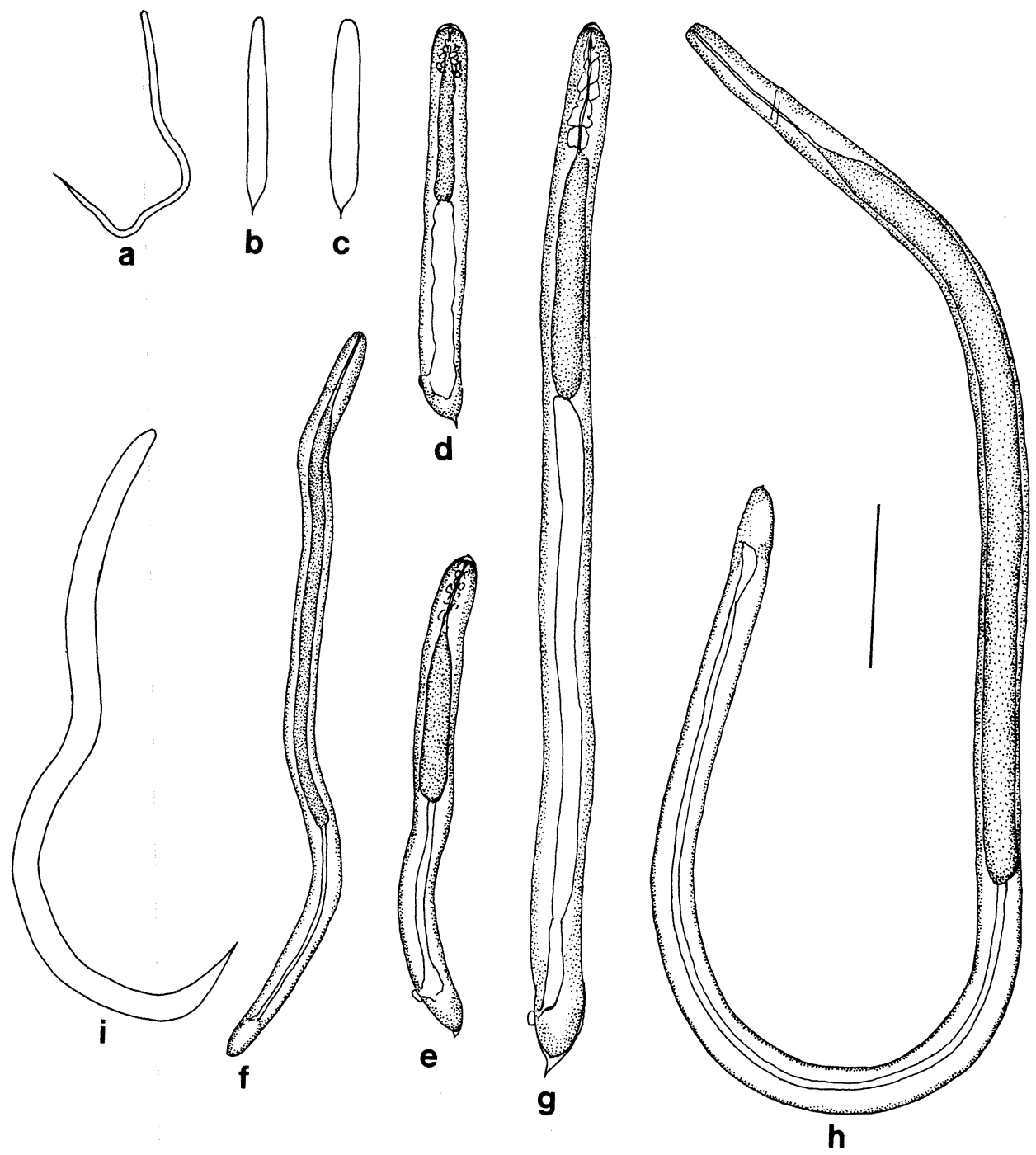

Figure 2 Filarial and non-filarial larvae found in Simulium spp. caught on a cow at the Omyojin Farm, Iwate, northeast Japan. a, microfilaria found in S. iwatense; b and c, first-stage larvae found in S. daisense; d, second-stage larva found in $S$. iwatense; e, second-stage larva found in S. nikkoense; f, third-stage larva of Onchocerca sp. (type B) found in S. daisense; g, preinfective larva of Onchocerca sp. (type A) found in S. daisense; h, third-stage larva of Onchocerca sp. (type A) found in S. aokii; i, non-filaria larva found in S. iwatense. All larvae were found in the thorax except type B larva (f) which was found in the head. Scale $=100 \mu \mathrm{m}$. 


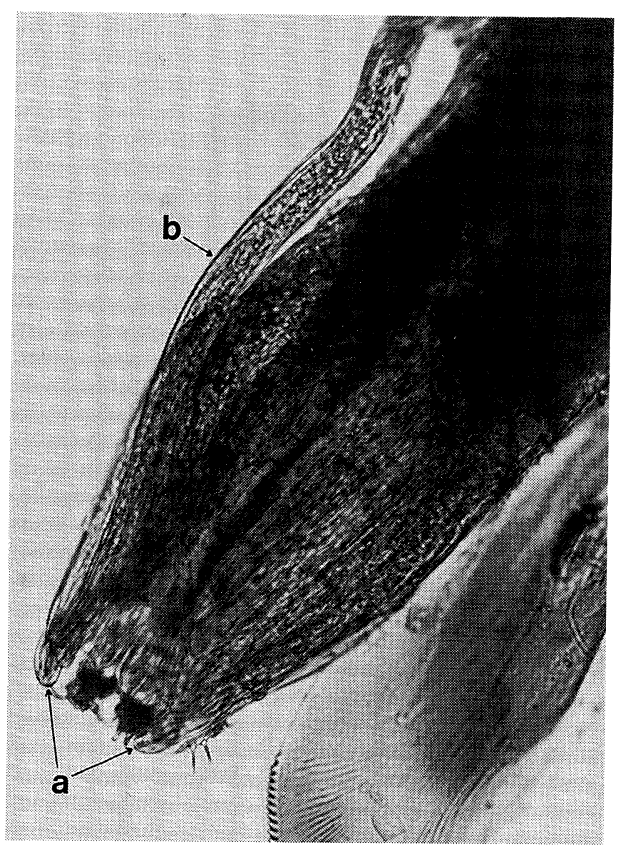

Figure 3 The labrum of the mouthpart of Simulium daisense clustered with many third-stage larvae of Onchocerca sp. (type B). a, anterior tip of two larvae; b, middle part of larval body.

bidentatum and S. arakawae (Takaoka and Bain, 1990) and was soon proved to be of bovine origin in Kyushu (Takaoka, 1990). In fact, it is difficult to separate type A from type I. The $\mathrm{L}_{3}$ larvae of Dirofilaria ursi Yamaguti of bears and $D$. immitis (Leidy) of dogs are somewhat similar to those of type A in having a long body size and small caudal lappets but their development takes place in the Malpighian tubules of the blackflies (Addison, 1980; Takaoka and Baba, 1987).

Type B, found in $S$. daisense, seems to conform to type III, $\mathrm{L}_{3}$ of $O$. lienalis parasitizing cattle, reported from S. arakawae and S. kyushuense in Kyushu too (Takaoka and Bain, 1990; Takaoka, in preparation). The body length of type B (369.4-477.6 $\mu \mathrm{m}$, average $435.4 \mu \mathrm{m})$ is shorter than that of type III $(510-530 \mu \mathrm{m})$ reported by Takaoka and Bain (1990). This gap is attributed mainly to the difference in the fixative solution used (ethanol vs. formalin).

The finding that $\mathrm{L}_{3}$ larvae of type $\mathrm{B}$ were found together with preinfective larvae of type A in the same fly, though once only, strongly suggests that both of these types share the same animal as a definitive host.

From these results as well as high biting and infection rates of $S$. daisense caught on the cow, it is likely that both type A and B are a bovine parasite. However, further studies are needed to confirm this observation since no data has been available yet on the Onchocerca infection in cattle bred in and near the Omyojin Farm, and also on the biting preference of these blackflies to other animals. Whether or not the filarial larvae found in $S$. iwatense and S. nikkoense are a bovine Onchocerca remained to be studied. 
Our results could add two more blackfly species, $S$. daisense and $S$. aokii, as a natural vector of zoonotic Onchocerca in Japan, though the latter species has been reported as an experimental vector of type I in Kyushu (Takaoka, 1990).

The biting activities of blackflies were observed throughout the surveyed period from April to November. And, four of these eight months (i.e., from June to September) were expected as the probable period for Onchocerca transmission in and near the Omyojin Farm from the air temperature conditions. However, actual transmission time of these zoonotic Onchocerca spp. would be more restricted, because female blackflies carrying $\mathrm{L}_{3}$ larvae were collected only in July.

\section{ACKNOWLEDGEMENTS}

We would like to thank Prof. H. Itagaki, Azabu University, and Prof. I. Inoue, Nihon University, Kanagawa, for their kindness in providing valuable information and references on bovine onchocerciasis and its transmission in Japan. Our appreciation goes to Miss K. Ogata, Medical College of Oita, for her assistance in dissecting flies. This study was in part supported by a Grant-in-Aid for Scientific Research from the Ministry of Education, Science and Culture of Japan (No. 01570216).

\section{REFERENCES}

1) Addison, E.M. (1980): Transmission of Dirofilaria ursi Yamaguti, 1941 (Nematoda: Onchocercidae) of black bears (Ursus americanus) by blackflies (Simuliidae), Can. J. Zool., 58, 19131922

2 ) Bain, O. and Chabaud, A.G. (1986): Atlas des larves infestantes de filaires, Trop. Med. Parasit., 37, $301-340$

3 ) Hosoya, H., Tamae, K. and Sukegawa, S. (1956): On the microfilaira in blackflies and sandflies collected from area of "Wahi" and "Kasen" disease, J. Tokyo Soc. Vet. Zootech. Sci., 6, 7-13

4) Takaoka, H. (1990): Development of microfilariae of two bovine Onchocerca species in blackflies in Japan, Jpn. J. Trop. Med. Hyg., 18, 183-188

$5)$ Takaoka, H. and Baba, M. (1987): Experimental infection of Simulium takahasii with a canine filaria Dirofilaria immitis, Jpn. J. Sanit. Zool., 38, 1-6

$6)$ Takaoka, H. and Bain, O. (1990): Infections of blackflies (Diptera: Simuliidae) with three types of zoonotic Onchocerca larvae in Oita, Japan, Jpn. J. Trop. Med. Hyg., 18, 1-10

7 ) Takaoka, H., Ochoa, J.O., Juarez, E.L. and Hansen, K.M. (1982): Effects of temperature on development of Onchocerca volvulus in Simulium ochraceum, and longevity of the simuliid vector, J. Parasit., 68, 478-483

8 ) Ueno, H., Kitaoka, S., Ishihara, T. and Yajima, A. (1956): Studies on the species and seasonal incidence of Culicoides in Tokyo area, Jpn. J. Sanit. Zool., 7, 19-26 
東北地方のブユ成虫におけるオンコセルカ幼虫自然感染

高岡 宏行 ${ }^{1}$ 青木 千春 ${ }^{1}$ ・早川 博文 ${ }^{2}$

岩手県零石町御明神牧場において，1989年 4 月から11月にかけて，牛囮法で合計12種のブユを 得た。6月一8 月に比較的捕獲数の多い Simulium aokii, S. daisense, S. iwatense および S. nikkoenseの 4 種3,098個体を解剖し，それぞれ0.8\% (7/913)，4.4\% (48/1,104)，0.5\% (4/741), $0.9 \%(3 / 340)$ にフィリア幼虫の感染を認めた。S. aokii 除く他の 3 種のブユからは, 今回初 めてフィラリア幼虫が見付かった。第三期幼虫 $\left(\mathrm{L}_{3}\right)$ は, 7 月に採集された $S$. aokii および $S$. daisense から得られた。 $\mathrm{L}_{3}$ の形態から 2 種が含まれていることが分かった。type $\mathrm{A}$ は両種ブユか ら見いだされたが, type B は S. daisense からのみ得られた。type A および B は, それぞれ九州 のブユから得られている Onchocerca type I, II, III のうちの type I (牛に寄生するO. sp.) と type III (O. lienalis) と思われる。他の 2 種のブユからは $\mathrm{L}_{3}$ は得られなかったので，フィラリア 種の同定は出来なかった。動物寄生性オンコセルカに感染された人体症例が, 既に九州から報告 されているが, 今回の調査により, 本州においてもブユの媒介による, 同様の人体感染例が発生 する可能性が示唆された。

\footnotetext{
1 大分医科大学医動物学教室

2 農林水産省東北農業試験場家畜虫害研究室
} 